Scientia Marina 70(4)

December 2006, 573-583, Barcelona (Spain)

ISSN: 0214-8358

\title{
Molluscan diversity along a Mediterranean soft bottom sublittoral ecotone
}

\author{
PANAYOTA KOULOURI ${ }^{1}$, COSTAS DOUNAS ${ }^{1}$, CHRISTOS ARVANITIDIS ${ }^{1}$, \\ DROSOS KOUTSOUBAS ${ }^{2}$ and ANASTASIOS ELEFTHERIOU ${ }^{3}$ \\ ${ }^{1}$ Hellenic Centre for Marine Research, Institute of Marine Biology and Genetics, Gournes Pediados, P.O. Box 2214, \\ 71003, Heraklion, Crete, Greece. E-mail: yol72@her.hcmr.gr \\ ${ }^{2}$ University of the Aegean, Department of Marine Science, Sapfous 5, 81100, Mytilene, Greece. \\ ${ }^{3}$ University of Crete, Department of Biology, P.O. Box 2208, Vasilika Vouton, 71409, Heraklion, Crete, Greece.
}

SUMMARY: Molluscan diversity associated with sublittoral soft-bottoms was studied in Heraklion Bay as part of a longterm multidisciplinary research programme in the coastal environment of northern Crete (eastern Mediterranean). Quantitative benthic samples were collected in a pilot survey from a grid of 28 stations, followed by a seasonal sampling carried out over a seven- station transect located from 10 to $40 \mathrm{~m}$ depth. Univariate and multivariate analyses indicated the presence of a clear zonation along the depth gradient for the molluscan fauna and three main associations were identified in bathymetric zones parallel to the coastline. The structure of the local molluscan communities revealed the existence of an extended transition zone (ecotone) between a shallow sandy association and a deeper muddy one and a functional pattern, based on the feeding guilds, was evident along the environmental gradient. Application of graphical techniques, by using molluscan taxocoenosis, indicated a rather naturally disturbed habitat. Beta-diversity measures indicated different seasonal community adaptations to the prevailing environmental conditions. Results derived from this study revealed that beta-diversity may be a good descriptor for the assessment of the strength and breadth of sublittoral transition zones along environmental gradients.

Keywords: mollusc diversity, ecotone, sublittoral, soft bottom, beta-diversity, perturbation, environmental assessment, eastern Mediterranean.

RESUMEN: DiversidAd MALACOLÓGICA EN UN ECOTONO SUblitoral MEDITERRÁNEO DE FONDOS BLANDOS. - La diversidad malacológica asociada a la zona infralitoral de fondos blandos se ha estudiado en la bahía de Heraklion como parte de un programa de investigación multidisciplinar a largo plazo en la costa norte de Creta (Mediterráneo Oriental). Muestras cuantitativas del bentos fueron recogidas durante un muestreo piloto realizado en una parrilla de 28 estaciones. A continuación se realizó un muestreo estacional en un transecto de siete estaciones situadas entre 10 y $40 \mathrm{~m}$ de profundidad. Los análisis univariables y multivariables indicaron la presencia de una clara zonación malacológica a lo largo del gradiente de profundidad, identificándose tres asociaciones principales en zonas batimétricas paralelas a la línea de costa. La estructura de las comunidades locales de moluscos puso de manifiesto la existencia de una extensa zona de transición (ecotono) entre la asociación de arena somera y la de fango profundo y evidenció un patrón funcional basado en los tipos de alimentación a lo largo del gradiente ambiental. La aplicación de técnicas gráficas, empleando la taxocenosis de moluscos, indicó un hábitat perturbado. Lla diversidad beta indicó diferentes adaptaciones de las comunidades estacionales a las condiciones ambientales reinantes. Los resultados obtenidos en este estudio muestran que la diversidad beta puede ser un buen descriptor para la evaluación de la capacidad y la amplitud de las zonas de transición sublitoral a lo largo de gradientes ambientales.

Palabras clave: diversidad malacológica, ecotono, sublitoral, fondos blandos, diversidad beta, perturbación, evaluación ambiental, Mediterráneo oriental. 


\section{INTRODUCTION}

The European Water Framework Directive (WFD; Directive 2000/60/EC) gives emphasis to the assessment of the Ecological Quality Status (EcoQ) of coastal and transitional waters, as these highly dynamic systems are usually exposed to anthropogenic forcing. Although macrozoobenthos is among the basic biological elements in the WFD, the benthic community approach has received criticism because the procedures involved, such as sampling, sample analysis and computing, are too time-consuming and labour-intensive to be costeffective in environmental assessments (Warwick et al., 1990). The use of different sieve mesh sizes (Thompson et al., 2003) and the application of subsampling techniques (Carey and Keough, 2002) have been proposed for the establishment of more cost-effective methods. Additionally multivariate techniques (Olsgard et al., 1997) and recently developed sample-size/sample-effort free biodiversity indices have also been used as an alternative to species-level identification of the total fauna (e.g. Warwick and Clarke, 2001). Therefore, it has been proposed that the diversity of single taxonomic groups, e.g. amphipods (Gómez-Gesteira and Dauvin, 2000), cumaceans (Corbera and Cardell, 1995) and polychaetes (Samuelson, 2001), could be used as an indicator of environmental stress and pollution.

Although benthic molluscs have been used as descriptors of sublittoral soft-bottom benthic communities (Zenetos, 1996; Rueda et al., 2001), there is no information concerning their use as an appropriate taxonomic group for the detection and discrimination of community response to natural or anthropogenic-induced forcing. The present study is part of a long-term multidisciplinary research programme of the Hellenic Centre for Marine Research in the coastal environment of northern Crete (Eastern Mediterranean), and especially in Heraklion Bay, with the main objective of investigating the structure and function of the benthic ecosystem in this area (Dounas and Papadopoulou, 1993; Karakassis and Eleftheriou, 1997; Koulouri et al., 2000; Tselepides et al., 2000). The detailed objectives of the present study were: (a) to describe the bathymetric distribution and seasonal variability of the sublittoral soft bottom molluscan taxocoenosis by performing a series of uni-, multivariate and graphical methods; (b) to identify the environmental factors which are instrumental in determining the molluscan community structure; and (c) to investigate the applicability of the turnover diversity measurements as a potential descriptor of the molluscan community responses to natural or anthropogenicinduced environmental perturbations in this specific coastal environment.

\section{MATERIALS AND METHODS}

\section{Study area}

The present study was conducted in the sublittoral zone of Heraklion Bay at depths of 10 to 40 metres, covering an area exposed to wave action along a coastline stretching more than $18 \mathrm{~km}$ (Fig. 1 ). The coastal zone is affected by small-scale freshwater inputs and urban waste discharges, while the offshore system is characterised by marked oligotrophy (Karakassis and Eleftheriou, 1997; Psarra et al., 2000). The study area is located outside the local bottom trawling fishing grounds.

A detailed description of the environmental variables measured seasonally in the surface sediments of the study area is given in Dounas and Papadopoulou (1993). In summary, sediment temperature, taken $2 \mathrm{~cm}$ below the sediment surface, shows strong seasonality, ranging from $14.2^{\circ} \mathrm{C}$ in winter to $24.0^{\circ} \mathrm{C}$ in summer. Overall temperature gradually decreases with depth, with a particular sharp decrease observed at the $40 \mathrm{~m}$ station in summer and autumn indicating the depth of the seasonal thermocline. Surface sediment redox potential (Eh) values range from $86 \mathrm{mV}$ in summer to $454 \mathrm{mV}$ in winter, indicating moderately to well-oxygenated sediments throughout the year. Lower Eh values are generally observed in the deeper muddy areas. Chlorophyll- $a$ concentrations in the sediment range from $0.14 \mu \mathrm{g} \mathrm{g}^{-1}$ in winter to $1.83 \mu \mathrm{g} \mathrm{g}^{-1}$ in spring, with higher values recorded at the intermediate depths. Phaeopigment concentrations gradually increase with depth and range from $0.10 \mu \mathrm{g} \mathrm{g}^{-1}$ in autumn to $4.71 \mu \mathrm{g} \mathrm{g}^{-1}$ in spring. Total organic carbon (TOC) values range from $0.21 \mathrm{mg} \mathrm{g}^{-1}$ in summer to $8.43 \mathrm{mg} \mathrm{g}^{-1}$ in winter, with the highest values in the deeper areas throughout the year. Sediment particle size decreases with depth in all seasons. Therefore, while sediments deeper than $20 \mathrm{~m}$ contain higher percentages of mud (60.85 to $90.97 \%$ ), shallower depths consist mainly of sand (89.29 to $96.47 \%)$. It 


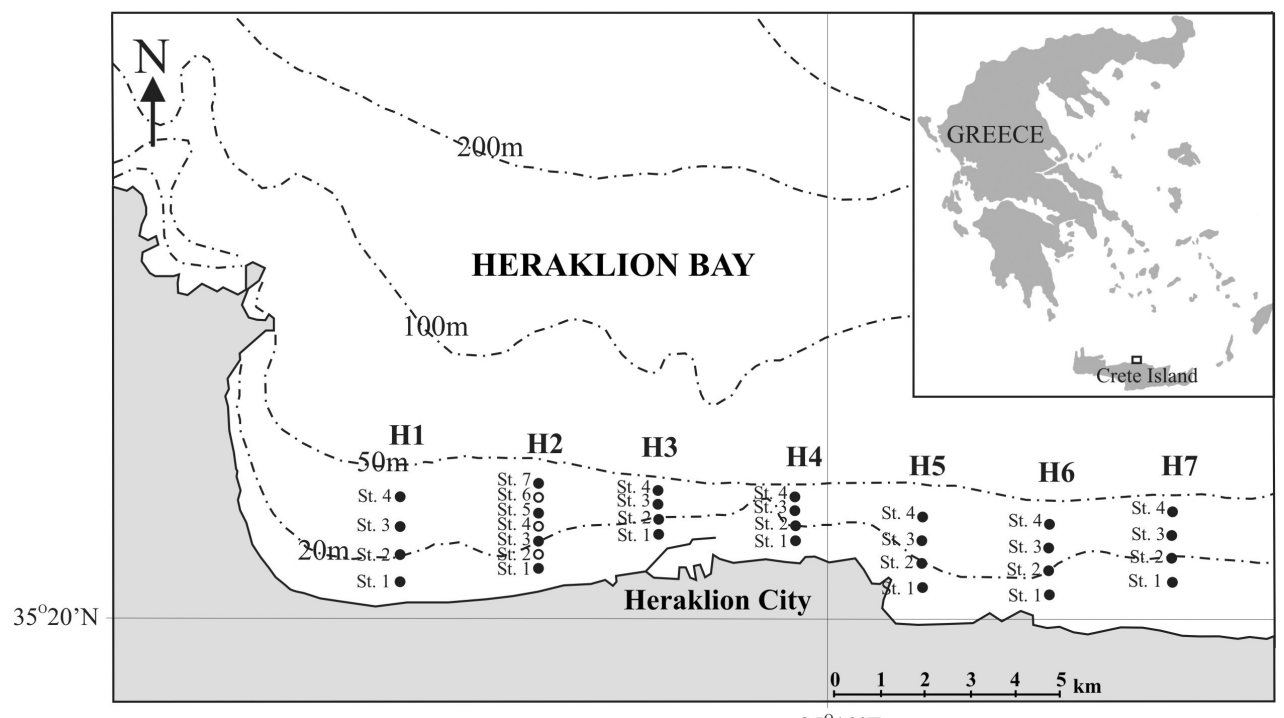

FIG. 1. - Map of Heraklion Bay showing the sampling stations (10, 20, 30 and $40 \mathrm{~m})$ of the seven transects sampled during the pilot survey (July 1990) and the location of the seven stations (10, 15, 20, 25, 30, 35 and $40 \mathrm{~m}$ ) along the transect $\mathrm{H} 2$ sampled during the following four surveys (October 1990, February, May and July 1991).

is worth mentioning that a seasonal shift in sediment type observed at about $20 \mathrm{~m}$ depth changes from mud $(83.12 \%$ silt $)$ in winter to sandy mud (14.35 to $33.23 \%$ silt) throughout the rest of the year.

\section{Sampling techniques}

A pilot field survey was carried out at 28 stations over seven transects (H1-7) at 10, 20, 30 and $40 \mathrm{~m}$ depths (Fig. 1). The coverage of the sublittoral zone, in terms of sampling effort, was approximately proportional to the size of the study area. Sampling was carried out in July 1990 using the R/V Philia. This exploratory study was then followed by four surveys undertaken over a representative transect $(\mathrm{H} 2)$, consisting of seven stations (from 10 to $40 \mathrm{~m}$ at $5 \mathrm{~m}$ depth intervals, Fig. 1), sampled on a seasonal basis (October 1990, February, May and July 1991). The positions of each station were calculated using a FURUNO SFN-70 satellite navigator and depth was measured by the SIMRAD K-400 echo sounder. In the pilot survey, a single sample was taken for macrofaunal analysis at each station, while five replicate samples were taken in the seasonal surveys using a $0.1 \mathrm{~m}^{2}$ top-opening Smith McIntyre grab (Smith and McIntyre, 1954). The samples were sieved on board through a $0.5 \mathrm{~mm}$ mesh size and fixed in neutralised formalin (10\%). Samples were sorted in the laboratory after being stained for $24 \mathrm{~h}$ with Rose Bengal and preserved in ethyl alcohol (70\%). Molluscs were identified to species level, counted and wet weighed (including their shells). A series of reference manuals were used for the classification of the specimens and can be found in Koutsoubas (1992), Zenetos (1996), Delamotte and Vardala-Theodorou (2001), while the nomenclature followed was that adopted by Sabelli et al. (1990). Shell-free dry weight (SFDW) calculations were made using the mean values of conversion factors given by Ricciardi and Bourget (1998). After identification, the molluscs were classified to feeding guilds according to Todd (2005).

\section{Data analysis}

Species richness was expressed at different spatial and temporal scales, i.e. replicates, stations (alpha diversity sensu Gray 2000), across depths (over all seasons) and within seasons (over all depths). Turnover diversity (or beta-diversity) was calculated using Whittaker's $\beta=(\gamma / \alpha)$-1, where $\gamma$ (gamma diversity) is the total number of taxa in the area and $\alpha$ is the average number of taxa per station (Gray, 2000). Whittaker's formula measures the degree to which an area is richer in species than the sampling stations within it. Cluster analysis, based on abundance matrices along the $\mathrm{H} 2$ transect of the four seasonal sampling periods, was performed using the Bray-Curtis similarity coefficient (Bray and Curtis, 1957). In order to investigate faunal similarities between stations (data transformed to the fourth root), an ANOSIM (Analysis of Similarities) test was used to detect statistically significant differences between groups of stations. 
TABLE 1. - Feeding Guilds of the molluscan species found in the study area.

\begin{tabular}{|c|c|c|c|}
\hline Species & FG & & $\mathrm{F}$ \\
\hline Abra alba (Wood W., 1802)* & DPF & Mangelia unifasciata (Deshayes, 1835) & \\
\hline Abra prismatica (Montagu, 1808)* & DPF & Musculus costulatus (Risso, 1826)* & \\
\hline Acanthocardia echinata (Linnaeus, 1758) & SF & Myrtea spinifera (Montagu, 1803)* & DP \\
\hline Acanthocardia paucicostata (Sowerby G.B.II, 1841) & SF & Mysella bidentata (Montagu, 1803) & \\
\hline Acanthocardia tuberculata (Linnaeus, 1758) & SF & Neolepton sulcatulum (Jeffreys, 1859) & \\
\hline Acteon tornatilis (Linnaeus, 1758) & $\mathrm{C}$ & Neverita josephinia (Risso, 1826) & \\
\hline Anodontia fragilis (Philippi, 1836)* & DPF & Notolimea crassa (Forbes, 1844) & \\
\hline Anomia ephippium (Linnaeus, 1758) & SF & Nucula nitidosa (Winckworth, 1930)* & \\
\hline Aporrhais pespelecani (Linnaeus, 1758) & $\mathrm{H}$ & Nuculana pella (Linnaeus, 1767)* & \\
\hline Arca tetragona (Poli, 1795) & $\mathrm{SF}$ & Ennucula tenuis (Montagu, 1808) & DI \\
\hline Ascobulla fragilis (Jeffreys, 1856)* & $\mathrm{H}$ & Odostomia conoidea (Brocchi, 1814) & \\
\hline Atys jeffreysi (Weinkauff, 1868) & $\mathrm{H}$ & Oxynoe olivacea (Rafinesque, 1814) & \\
\hline Azorinus chamasolen (Da Costa, 1778 ) & SF & Palliolum incomparabile (Risso, 1826) & \\
\hline Bela menkhorsti (Aartsen, 1988) & $\mathrm{C}$ & Pandora pinna (Montagu, 1803) & \\
\hline Bela nebula (Montagu, 1908) & $\mathrm{C}$ & Paphia aurea (Gmelin, 1791) & \\
\hline Bittium reticulatum (Da Costa, 1778) & $\mathrm{H}$ & Parvicardium exiguum (Gmelin, 1791)* & \\
\hline Bolinus brandaris (Linnaeus, 1758)* & $\mathrm{C}$ & Parvicardium minimum (Philippi, 1836) & \\
\hline Cadulus jeffreysi (Monterosato, 1875) & $\mathrm{C}$ & Parvicardium scabrum (Philippi, 1844)* & \\
\hline Chamelea gallina (Linnaeus, 1758) & SF & Parvicardium scriptum (B.D.D., 1892) & \\
\hline Chlamys glabra (Linnaeus, 1758) & SF & Petalifera petalifera (Rang, 1828$)$ & \\
\hline Chlamys varia (Linnaeus, 1758 ) & SF & Phaxas adriaticus (Coen, 1933)* & \\
\hline Chryssalida farolita (Nordsieck F., 1972) & $\mathrm{C}$ & Phaxas pellucidus (Pennant, 1777) & \\
\hline Chryssalida terebellum (Philippi, 1844) & $\mathrm{C}$ & Philine aperta (Linnaeus, 1767)* & \\
\hline Clausinella brongniartii (Payraudeau, 1826) & SF & Pitar rudis (Poli, 1795) & \\
\hline Corbula gibba (Olivi, 1792)* & SF & Plagiocardium papillosum (Poli, 1795)* & \\
\hline Ctena decussata (Costa O.G., 1829)* & DPF & Propeamussium fenestratum (Forbes, 1844) & \\
\hline Cyclopecten hoskynsi (Forbes, 1844) & SF & Psammobia fervensis (Gmelin, 1791) & \\
\hline Dentalium inaequicostatum (Dautzenberg, 1891)* & $\mathrm{C}$ & Psammobia tellinella (Lamarck, 1818) & \\
\hline Donax semistriatus (Poli, 1795) & SF & Pussilina sp. & \\
\hline Donax trunculus (Linnaeus, 1758) & SF & Retusa truncatula (Bruguiere, 1792) & \\
\hline Dosinia lupinus (Linnaeus, 1758) & SF & Ringicula conformis (Monterosato, 1877)* & \\
\hline Eubranchus exiguus (Alder and Hancock, 1848) & $\mathrm{C}$ & Rissoa monodonta (Philippi, 1836) & \\
\hline Eubranchus farrani (Alder and Hancock, 1848) & $\mathrm{C}$ & Rissoa violacea (Desmarest, 1814) & \\
\hline Eulima glabra (Da Costa, 1778) & $\mathrm{C}$ & Smaragdia viridis (Linnaeus, 1758)* & \\
\hline Euspira nitida (Donovan, 1804) & $\mathrm{C}$ & Solecurtus scopula (Turton, 1822) & \\
\hline Fustiaria rubescens (Deshayes, 1826 )* & $\mathrm{C}$ & Solemya togata (Poli, 1795) & \\
\hline Gibbula ardens (Von Salis, 1793) & $\mathrm{H}$ & Syrnola unifasciata (Forbes, 1844) & \\
\hline Gibbula racketti (Payraudeau, 1826) & $\mathrm{H}$ & Syrnola wenzi (Nordsieck F., 1972) & \\
\hline Glans aculeata (Poli, 1795) & SF & Tellimya ferruginosa (Montagu, 1808)* & \\
\hline Glans trapezia (Linnaeus, 1767) & SF & Tellina balaustina (Linnaeus, 1758 ) & \\
\hline Gouldia minima (Montagu, 1803)* & SF & Tellina compressa (Brocchi, 1814) & \\
\hline Hadriania oretea (De Gregorio, 1885) & $\mathrm{C}$ & Tellina crassa (Pennant, 1777) & \\
\hline Hiatella arctica (Linnaeus, 1767) & SF & Tellina donacina (Linnaeus, 1758) & \\
\hline Hyala vitrea (Montagu, 1803 ) & $\mathrm{H}$ & Tellina pulchella (Lamarck, 1818)* & \\
\hline Ischnochiton rissoi (Payraudeau, 1826) & $\mathrm{H}$ & Tellina serrata (Brocchi, 1814) & \\
\hline Jujubinus striatus (Linnaeus, 1758) & $\mathrm{H}$ & Thracia corbuloides (Deshayes, 1830) & \\
\hline Lepidopleurus scabridus (Jeffreys, 1880) & $\mathrm{H}$ & Thracia papyracea (Poli, 1791) & \\
\hline Lissopecten hyalinus (Poli, 1795) & $\mathrm{SF}$ & Thyasira flexuosa (Montagu, 1803)* & DI \\
\hline Lobiger serradifalci (Calcara, 1840) & $\mathrm{H}$ & Timoclea ovata (Pennant, 1777)* & \\
\hline Loripes lacteus (Linnaeus, 1758) & DPF & Tricolia pullus (Linnaeus, 1758) & \\
\hline Lucinella divaricata (Linnaeus, 1758) & SF & Tricolia tenuis (Michaud, 1829) & \\
\hline Lunatia sp.* & & Turbonilla gradata (B.D.D., 1883) & \\
\hline Lyonsia norwegica (Gmelin, 1791) & SF & Turritella communis (Risso, 1826) & \\
\hline Mactra sp. & & Volvulella acuminata (Bruguiere, 1792) & \\
\hline Mangelia attenuata (Montagu, 1803) & $\mathrm{C}$ & & \\
\hline
\end{tabular}

FG: feeding guild; H: herbivorous; C: carnivorous; SF: suspension feeder; DPF: deposit feeder; $*$ : asterisk indicates molluscan species also found in the pilot survey (July 1990).

Species contribution to the similarity of the stations and dissimilarity among groups of stations was investigated using the SIMPER (Similarity Percentage Procedure) technique. Environmental variables best correlated with the distribution pattern of the molluscan community were examined by means of the harmonic rank correlation coefficient $\left(\rho_{\mathrm{w}}\right)$, as proposed by Clarke and Ainsworth (1993), over the four seasonal surveys. Ecosystem disturbance was investigated using the distribution of species in geometric abundance and geometric size classes. The percentage of species was plotted against the number of individuals per species in geometric abundance classes and against the mean 
shell-free dry weight biomass per species in geometric size classes. An additional technique utilised included the abundance/biomass comparison (ABC) curves plotted for each seasonal sampling period. All the above-mentioned techniques are fully described in Clarke and Warwick (1994). The PRIMER statistical software package developed in Plymouth Marine Laboratory was used.

\section{RESULTS}

A total of 12159 specimens was identified to 109 species of molluscs (Table 1). Only 26 species were recorded in the pilot survey (28 samples) and all of these were included in the subsequent seasonal surveys. However, when sampling effort concentrated on the $\mathrm{H} 2$ transect (35 samples in each season) the total number of species increased from 46 in winter to 79 in summer. Bivalvia and Gastropoda were the most abundant classes, accounting for 59 and 36\% of the total fauna, respectively, followed by Scaphopoda (3 species) and Polyplacophora (2 species). Average density over the entire year was 842 individuals $\mathrm{m}^{-2}$ and shell-free dry weight biomass averaged $0.23 \mathrm{~g} \mathrm{~m}^{-2}$. Deposit and suspension feeders were numerically the two main functional groups throughout the year, accounting for up to 52.59 and $38.34 \%$ of the total molluscan abundance, respectively, followed by herbivores and carnivores. Generally, deposit feeders had higher abundances at the intermediate and deeper stations ( $20 \mathrm{~m}$ to $40 \mathrm{~m}$ ), while suspension feeders occupied the shallower stations (10 $\mathrm{m}$ and $15 \mathrm{~m})$.

Seasonal variations of species richness (S), averaged density (number of individuals $\mathrm{m}^{-2}$ ) and shellfree dry weight biomass $\left(\mathrm{g} \mathrm{m}^{-2}\right)$ generally showed the same pattern along the $\mathrm{H} 2$ transect (Fig. 2).

\section{Autumn}
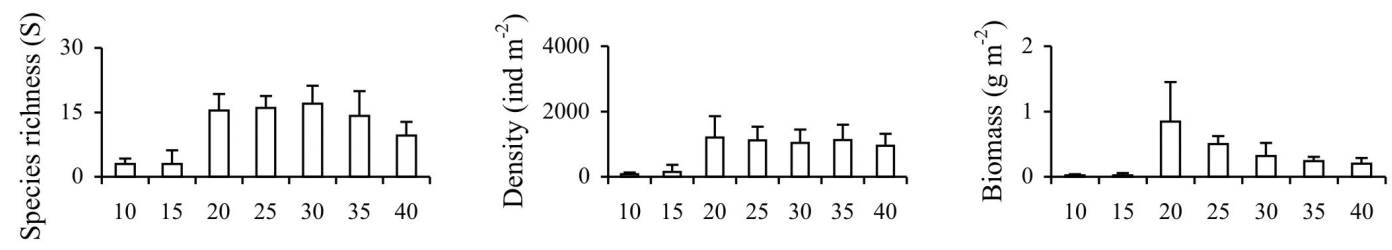

Winter
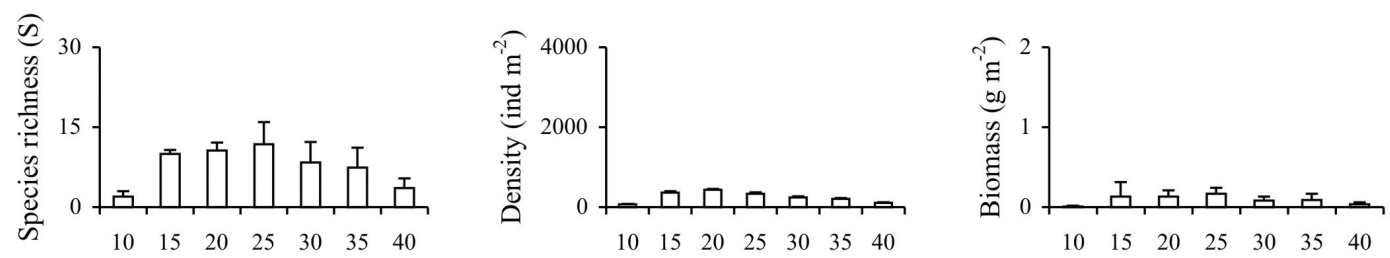

Spring
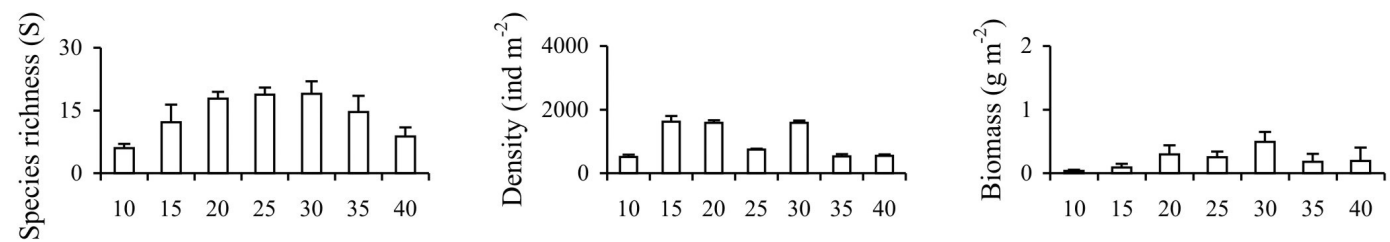

\section{Summer}
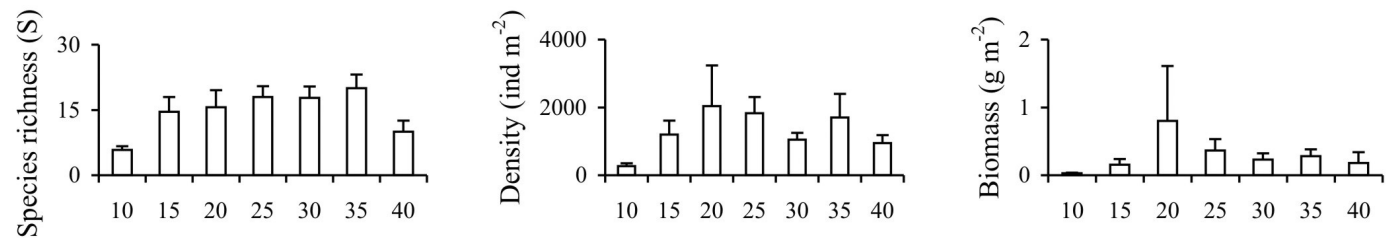

\section{DEPTH (m)}

FIG.2. - Seasonal changes of molluscan diversity, density, and biomass (shell-free dry weight) of the seven stations in the study area (aver age values and standard deviation of the five replicate samples for each station). 

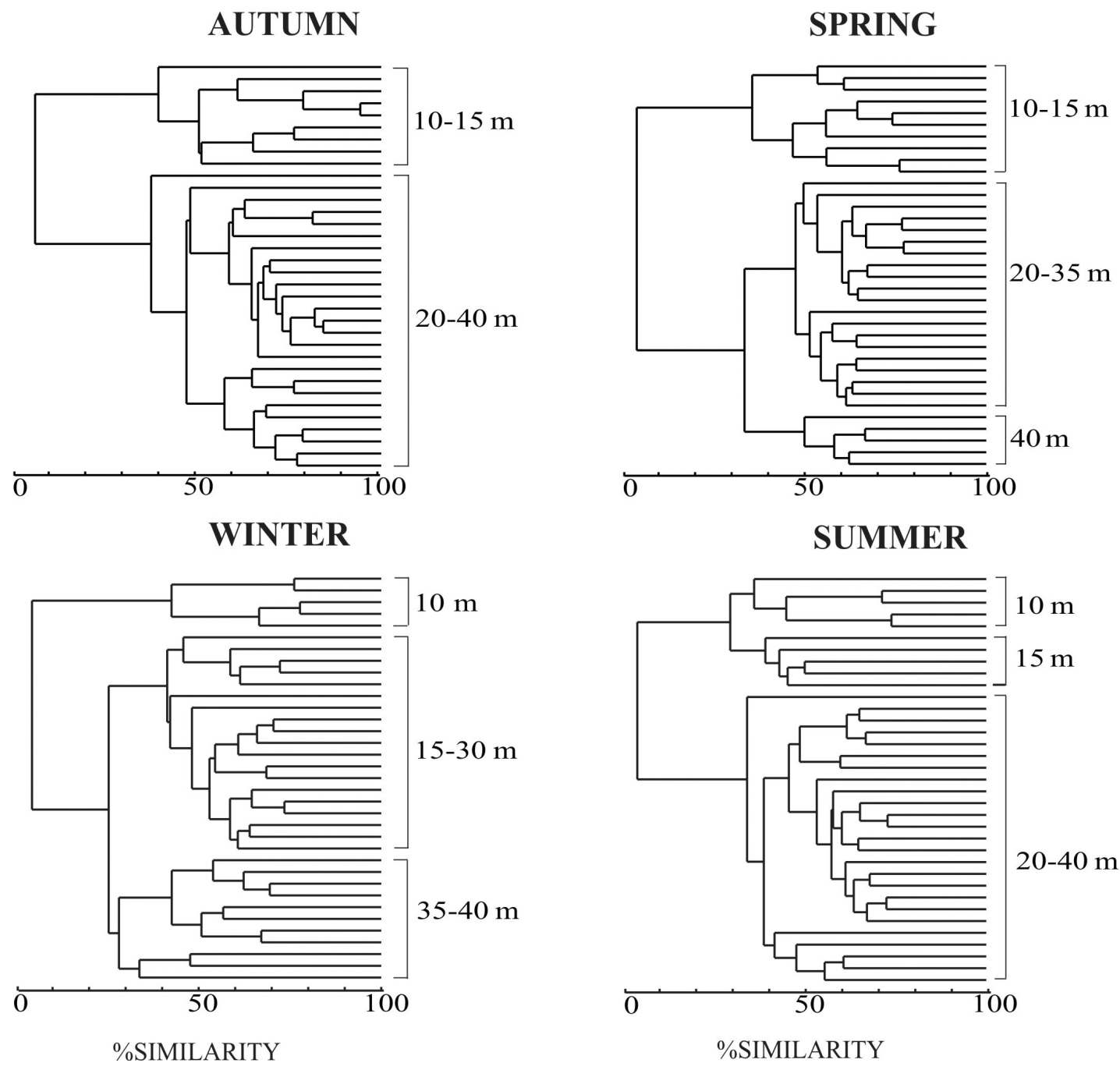

FIG.3. - Similarity dendrograms based on abundance matrices of the four seasonal sampling periods.

Higher values were recorded at the stations of intermediate depths ( 20 to $35 \mathrm{~m}$ ). In general there was a sharp increase in all the above parameters from winter to spring, followed by a gradual decrease from summer to autumn at all stations, with the exception of averaged shell-free dry weight biomass, which increased slightly from summer to autumn. The most pronounced seasonal changes were observed at the shallower sandy stations (10 and $15 \mathrm{~m}$ ).

The faunal similarity between stations for each sampling period is shown in Figure 3. It was observed that in autumn two distinct groups of stations could be detected, the first consisting of the two shallower stations at $10 \mathrm{~m}$ and $15 \mathrm{~m}$, and the second consisting of the deeper stations. The application of the SIMPER technique to the former revealed that the bivalves Lucinella divaricata and Tellina compressa made an important contribution
(62.79 and $30.83 \%$ respectively) to the similarity of these two stations. In the second group Thyasira flexuosa, Nucula nitidosa, Corbula gibba and Myrtea spinifera were the most abundant species. The results of the ANOSIM test showed that these two groups were significantly different $(\mathrm{R}=1$, $\mathrm{p}<0.01)$. In winter, three distinct station groups were evident $(\mathrm{R}=0.8, \mathrm{p}<0.01)$. The first group consisted of all the samples collected at $10 \mathrm{~m}$, with T. compressa and $L$. divaricata being the most abundant species. The bivalves Anodontia fragilis, Tellina pulchella, Gouldia minima and M. spinifera and the gastropod Ascobulla fragilis were mostly responsible for the similarity between the 15, 20, 25 and $30 \mathrm{~m}$ stations which comprised the second group. A third group included the deeper 35 and $40 \mathrm{~m}$ stations, with the bivalves $M$. spinifera and C. gibba making a large contribution (55.91 and 18.27\%, 
TABLE 2. - Environmental factors best correlated with the distribution pattern of the molluscan community over the four seasonal sampling periods.

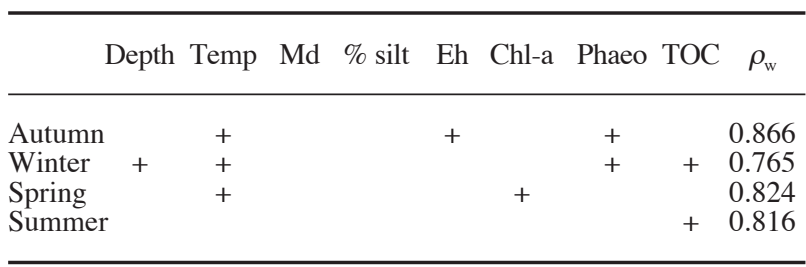

respectively) to their similarity. In spring, there were also three distinct station groups $(\mathrm{R}=0.9, \mathrm{p}<0.01)$. The first consisted of the shallower stations at 10 and $15 \mathrm{~m}$ where the bivalves $T$. compressa and $L$. divaricata were mostly responsible (33.73 and $21.39 \%$, respectively) for their similarity. The second included the intermediate stations ( 20 to $35 \mathrm{~m}$ ), with A. fragilis, T. flexuosa and G. minima being the most abundant species. In the third group the bivalves $N$. nitidosa and Abra prismatica made a large contribution (20.08 and $19.04 \%$ respectively) to the similarity of the samples at $40 \mathrm{~m}$. In summer, it was the bivalves $T$. compressa and Donax semistriatus that were mostly responsible (40.71 and $36.08 \%$, respectively) for the similarity of the samples from the $10 \mathrm{~m}$ station, which made up the first group. The second group consisted of the neighbouring station at $15 \mathrm{~m}$, with $L$. divaricata being the most abundant species. The third group comprised all the deeper stations ( 20 to $40 \mathrm{~m}$ ), with the bivalves T. flexuosa and A. fragilis being the most abundant species, making a large contribution (18.87 and $15.8 \%$, respectively) to the similarity of these stations. The three groups were thus significantly different $(\mathrm{R}=0.9, \mathrm{p}<0.01)$. The highest $\rho_{\mathrm{w}}$ values derived from the performance of the BIOENV routine of the PRIMER package were found to be greater than 0.7 , showing a positive correlation between the multivariate pattern of molluscan com- munity structure and different combinations of the measured environmental variables over the four seasonal sampling periods (Table 2).

The species richness at different spatial and temporal scales is shown in Table 3. At the smallest scale, i.e. $0.1 \mathrm{~m}^{2}$, and taking all the seasonal sampling periods into account, an average of 12 species was found along the environmental gradient. At the station level $\left(0.5 \mathrm{~m}^{2}\right)$, which corresponds to the point or alpha species richness (sensu Gray, 2000), the average number of species increased to 24 . The lowest species number at all depths (stations) was obtained in winter, while the highest appeared in summer. $\beta_{\text {season, which measures species turnover }}$ diversity along the gradient for each season, showed its lowest value in spring and its highest in winter. Taking into account species richness at each depth in all seasons, the lowest numbers of species were found at the two edges of the gradient (10 and $40 \mathrm{~m}$ ) and the highest at the intermediate depths. Accordingly, $\beta_{\text {depth }}$, expressing annual turnover diversity at the different depths, shared the lowest values at the intermediate depths of 20 to $35 \mathrm{~m}$, while the highest value was obtained at $10 \mathrm{~m}$ depth.

The geometric abundance and size classes are presented by season in Figure 4 (A, B). The number of geometric abundance classes (Fig. 4A) ranged from seven to ten classes throughout all seasons. Generally, species percentage gradually decreased as the geometric abundance class increased. The number of geometric size classes ranged from eleven to thirteen classes over the four sampling periods (Fig. 4B). Small and moderate size classes represented the highest species percentage in all seasonal sampling periods. ABC curves along with the $\mathrm{W}$-statistic values are given in Figure 4C for each seasonal sampling period. All of the W-statistic values varied slightly close to zero, indicating moderately disturbed conditions throughout the year.

TABLE 3. - Number of species within the $\mathrm{H} 2$ transect in each seasonal sampling period and at the respective sampling depths.

\begin{tabular}{|c|c|c|c|c|c|c|c|c|}
\hline \multirow[b]{2}{*}{ Season } & \multirow[b]{2}{*}{$\begin{array}{c}\mathrm{SR}_{\mathrm{repl}} \\
\left(0.1 \mathrm{~m}^{2}\right)\end{array}$} & \multicolumn{2}{|c|}{ Within seasons } & \multirow[b]{2}{*}{$\beta_{\text {season }}$} & \multirow[b]{2}{*}{ Depth (m) } & \multicolumn{2}{|c|}{ Across depths } & \multirow[b]{2}{*}{$\beta_{\text {depth }}$} \\
\hline & & $\begin{array}{l}\mathrm{SR}_{\text {station }} \\
\left(0.5 \mathrm{~m}^{2}\right)\end{array}$ & $\mathrm{SR}_{\text {season }}$ & & & $\begin{array}{l}\text { SRstation } \\
\left(0.5 \mathrm{~m}^{2}\right)\end{array}$ & $\mathrm{SR}_{\text {depth }}$ & \\
\hline Autumn & $11.17 \pm 6.60$ & $22.29 \pm 11.04$ & 55 & 1.47 & 10 & $8.75 \pm 4.11$ & 25 & 1.86 \\
\hline Winter & $7.69 \pm 4.25$ & $17.14 \pm 7.22$ & 46 & 1.68 & 15 & $22.75 \pm 11.50$ & 53 & 1.33 \\
\hline Spring & $13.89 \pm 5.42$ & $26.86 \pm 9.62$ & 61 & 1.27 & 20 & $30.00 \pm 5.29$ & 59 & 0.97 \\
\hline \multirow[t]{4}{*}{ Summer } & $14.54 \pm 5.37$ & $30.86 \pm 9.10$ & 79 & 1.56 & 25 & $30.00 \pm 5.10$ & 49 & 0.63 \\
\hline & & & & & 30 & $29.75 \pm 6.13$ & 55 & 0.85 \\
\hline & & & & & 35 & $30.25 \pm 9.11$ & 52 & 0.72 \\
\hline & & & & & 40 & $17.50 \pm 6.24$ & 36 & 1.06 \\
\hline Total & $11.82 \pm 6.05$ & $24.14 \pm 10.13$ & & & & & 109 & 3.51 \\
\hline
\end{tabular}




\section{AUTUMN \\ WINTER \\ SPRING \\ SUMMER}
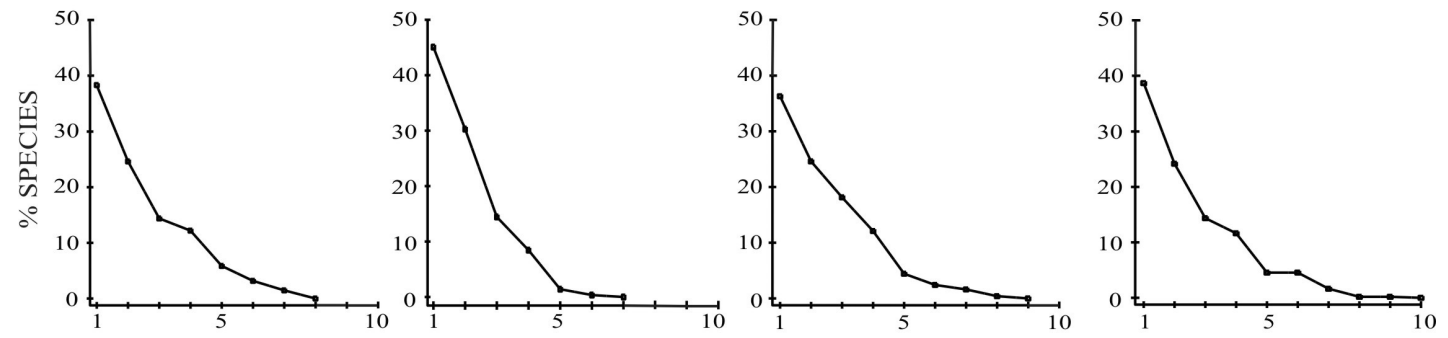

(A) GEOMETRIC ABUNDANCE CLASS
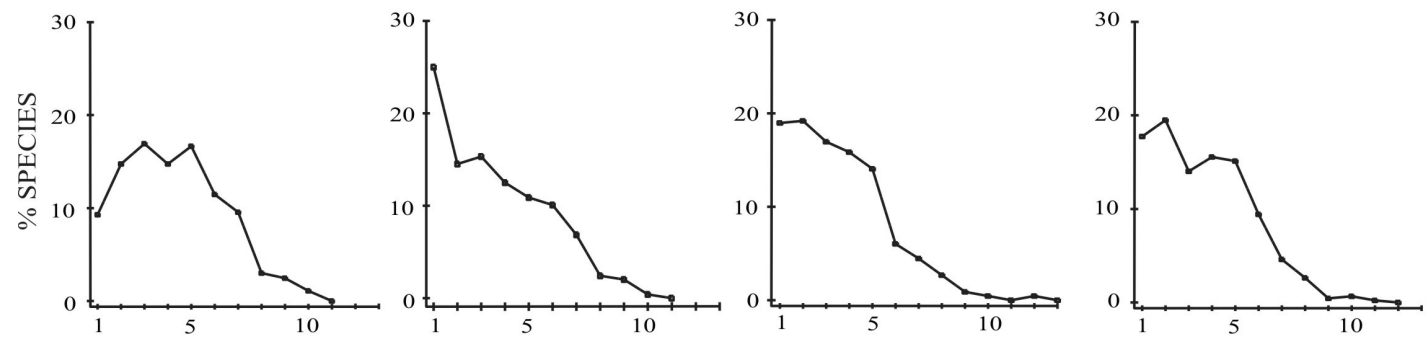

(B) GEOMETRIC BIOMASS CLASS
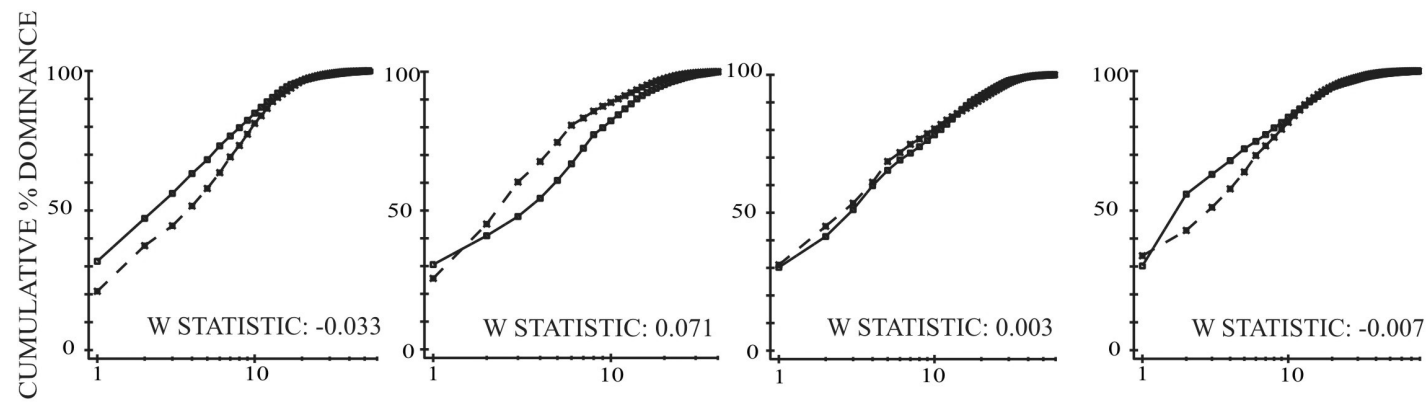

(C) SPECIES RANK

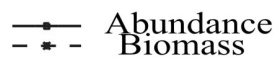

FIG.4. - Distribution of geometric abundance (A) and size classes (B) and ABC curves (C) of the four seasonal sampling periods.

\section{DISCUSSION}

The Convention on Biological Diversity requires the inclusion of biodiversity in environmental assessments (UNEP, 1992). Since resources for measuring biodiversity will always be limited, it is usually recommended to devote more effort to repeated measurements in space and time than to a few sites on a short timescale (Costello et al., 2004). In the soft-bottom sublittoral zone of Heraklion Bay the single observational field survey performed in summer along seven transects $\left(2.8 \mathrm{~m}^{2}\right.$ total surface sampled) revealed only 26 molluscan species. In contrast, the subsequent four seasonal surveys performed at seven stations located along a single transect $\left(14.0 \mathrm{~m}^{2}\right)$ revealed 109 species in total. This species richness is high when compared with the molluscan diversity recorded from the entire continental shelf of Crete (233 species, Koutsoubas et al., 1992).

However, it is usually the assemblage of organisms in an area that is important, rather than the number of species present in a specific area (Noss, 1983). The Mediterranean benthic ecosystem is generally described according to the classification scheme of benthic biocoenoses proposed by Pérès (1967). Despite the difficulties in the application of this scheme outside or in some cases even within the Mediterranean Sea (Karakassis and Eleftheriou, 1997), it may still be considered as useful for the description of distinct "organismic assemblages" sensu Pérès (1982) corresponding to different ecological conditions (Bellan Santini, 1985). 
According to the results of this study, three molluscan assemblages can be distinguished in the sublittoral zone of Heraklion Bay. The first one, at depths of 10-15 m, belongs to the shallow benthic biocoenosis of "fine well-sorted sands" (Pérès, 1967). The bivalves Tellina compressa, T. serrata, Lucinella divaricata, Mysella bidentata, Donax semistriatus, Phaxas adriaticus and Clausinella brongiartii and the gastropod Rissoa monodonta were found to be the most common species. The second assemblage, lying in the deeper part of the study area $(35-40 \mathrm{~m})$, belongs to the biocoenosis of the "coastal terrigenous muds" (Pérès, 1967). Several species characteristic of muddy substrates, such as the gastropod Turritella communis and the bivalves Abra prismatica, Corbula gibba, Myrtea spinifera, Nucula nitidosa and Thyasira flexuosa, were found to be the most abundant. Among these species, Corbula gibba, Abra prismatica, and Thyasira flexuosa are characterised as being tolerant to excess organic matter enrichment (Borja et $a l ., 2000)$. This biocoenosis is almost uniformly distributed over the outer part of the Cretan continental shelf (Karakassis and Eleftheriou, 1997). Between the two aforementioned assemblages, results revealed the existence of a broad transition zone, at depths of 20 to $35 \mathrm{~m}$, characterised by the highest values in molluscan species richness, density and biomass. This zone is enriched with species from both biocoenoses but also with some additional species, such as the bivalves Anodontia fragilis, Gouldia minima, Tellina pulchella, T. donacina, Plagiocardium papillosum, Musculus costulatus, Ctena decussata, Anomia ephippium and Volvulella acuminata and the gastropods Ascobulla fragilis, Hyala vitrea and Odostomia conoidea, which occurred only there. A shift in the bathymetric limits of the "fine well-sorted sands" biocoenosis, normally found at $15-20 \mathrm{~m}$, was observed in winter. During this period the molluscan assemblage showed the lowest diversity, abundance and biomass and was restricted to a shallower zone located at $10-15 \mathrm{~m}$ depth, probably due to intermittent disturbance by storms and increased runoff, which prevented the establishment of a long-term equilibrium between sediment composition and biological community structure (Newell et al., 2001). On the other hand, multivariate analysis failed to define clearly the shallower limits of the deeper "coastal terrigenous muds" biocoenosis, which was probably located at depths of 30-40 m.
The "fine well-sorted sands" biocoenosis was dominated by suspension feeders due to the frequent wave and/or current induced resuspension of finegrained sediments and their organic matter content, especially in winter. Though the transition zone and the "coastal terrigenous muds" biocoenosis, where more stable conditions prevail, were occupied primarily by deposit feeders, the presence of suspension feeders also remained important. Numbers of deposit feeders reached a peak in a zone around $20 \mathrm{~m}$ depth where most of the available particulate organic matter was largely accumulated in the sediment. This functional pattern is similar to observations from other coastal areas where a dominance of suspension feeders in shallow soft-bottoms of high hydrodynamism and the occupation of deposit feeders in deeper and therefore more stable environments have been reported (Dewarumez et al., 1992). However, it should be taken into account that many suspension feeders may also ingest deposited material and deposit feeders may take in material from the water column (Todd, 2005).

The observed depth-related pattern in molluscan distribution and diversity in this study is likely to reflect gradients in both physical conditions and food supply and refers to a transition from a "high energy" and a "stressed" sandy shallow environment to a deeper and more stable muddy one. This environmental setup corresponds to the erosion, high combustion and deposition sedimentary areas described by Graf (1992). Environmental variables, such as sedimentary organic carbon, chlorophyll $a$ and phaeopigments, considered as indicators of increased food availability in the depositional parts of the study area, are those correlated better with the seasonal distribution pattern of molluscan community. Nevertheless, it should be stressed here that food availability, as expressed by the low levels of TOC concentrations $\left(<10 \mathrm{mg} \mathrm{g}^{-1}\right)$ measured in the study area, does not seem to influence molluscan species richness (Hyland et al., 2005).

Investigations of turnover diversity in the marine environment have been few, and comparative studies are not easy to carry out due to the different ways in which turnover diversity has been measured (Gray, 2000). However, measuring turnover diversity is a way to assess the degree of change in species composition along an environmental gradient, or the extent of the difference from the opposite ends of a gradient (Gray, 2000). In the study area, beta diversity was measured for each season taking into 
account species richness at all stations and for each depth throughout all seasons. Species turnover along the gradient in winter was the highest, indicating that during this period the total assemblage structure was influenced by abrupt changes in environmental variables. In contrast, low turnover diversity in spring, i.e. higher similarity of species composition, may imply a temporary response of the molluscan assemblages to increased food availability. As far as species turnover across depths is concerned, the intermediate stations showed similar values that were lower than those of the shallower and deeper stations, suggesting that species composition in the transition zone remained very similar throughout the year. Results from this study revealed that measurement of turnover diversity may be a good descriptor for the assessment of the strength and breadth of transition zones along environmental gradients.

The broad sublittoral transition zone identified in Heraklion Bay can be considered as an ecotone, i.e. area of rapid change, between two different and relatively homogenous community types (BellanSantini, 1985). Ecotones are highly dynamic and relatively unstable systems resulting in "stress" zones (Attrill and Rundle, 2002). The sharpest ecotones are often induced by anthropogenic activities, such as organic enrichment and pollution (Pearson and Rosenberg, 1978), but there are also several natural examples (Attrill and Rundle, 2002). Results from the present study support the hypothesis of a transition scheme which could most probably be attributed mainly to natural forcing, like storms and winds, strength of currents and turbidity (Dewarumez et al., 1992). This is further supported by the sediment TOC concentrations measured in the study area, which are well below the lower critical point $\left(<10 \mathrm{mg} \mathrm{g}^{-1}\right)$ corresponding to coastal areas without organic loading and associated stressors (Hyland et al., 2005).

Two of the methods performed, i.e. the distribution of abundance and size classes, strengthen the hypothesis of a non-polluted community succession pattern. The distribution of the abundance classes shows that rare species are present in large numbers in all seasons, indicating a non-polluted system according to Gray and Pearson (1982). Furthermore, Pearson and Rosenberg (1978) suggested that the average individual size decreases in organically polluted areas, while Warwick et al. (1986) assumed that this applies to mean species size and that large species are lost with increasing organic enrichment and are replaced by smaller opportunistic species. In the present study the distribution of the geometric size classes showed a high number of size classes with the small and intermediate ones dominant at most stations. Such a distribution is not conducive to the hypothesis of a polluted habitat. On the contrary, $\mathrm{ABC}$ curves and $\mathrm{W}$-statistic values indicate that this habitat was in a moderately disturbed condition. Nevertheless, Warwick and Clarke (1994) suggest that in most cases of undisturbed communities indications of pollution or disturbance detected by this method should be viewed with caution if the species responsible for the polluted configurations are not polychaetes. In the light of this statement, the study of the seasonal and bathymetric structure of the coastal molluscan community in Heraklion Bay seemed to reveal a rather naturally disturbed habitat in a dynamic state that was highly influenced by the prevailing environmental conditions.

Although molluscan taxocoenosis may well offer several applications in environmental assessments, in combination with other taxa and diversity measures, their potential is currently under-utilised. The identification of the molluscan species is much easier than the identification of all macrobenthic taxa to the generic or family level, which has provided plausible results in a number of cases (e.g. Warwick et al., 1990). In addition, taxonomic groups like crustaceans and echinoderms are often absent from the most perturbed parts of gradients, while molluscs are more tolerant (Pearson and Rosenberg, 1978). Results of this study suggest that, by using only the molluscan taxocoenosis, the procedures involved in assessment of coastal marine environments subjected to natural or anthropogenic-induced forcing may be less time-consuming and labour-intensive.

\section{ACKNOWLEDGEMENTS}

This work was carried out in the framework of the project Environmental Monitoring of Heraklion Bay financed in part by the Water Board Authority of Heraklion city. The authors acknowledge the support provided by the captain and the crew of the R/V Philia.

\section{REFERENCES}

Attrill, M.J. and S.D. Rundle. - 2002. Ecotone or Ecocline: Ecological Boundaries in Estuaries. Estuar. Coast. Shelf Sci., 55: $929-936$. 
Bellan-Santini, D - 1985. The Mediterranean Benthos: Reflections and problems raised by a classification of the benthic assemblages. In: M. Moraitou-Apostolopoulou and V. Kiortsis (eds.), Mediterranean Marine Ecosystems, pp. 19-48. Plenum Press, New York.

Borja, A., J. Franco and V. Pérez. - 2000. A Marine Biotic Index to Establish the Ecological Quality of Soft-Bottom Benthos Within European Estuarine and Coastal Environments. Mar. Pollut. Bull., 40(12): 1100-1114.

Bray, J.R. and J.T. Curtis. - 1957. An ordination of the upland forest communities of southern Wisconsin. Ecol. Monogr., 27: 325-349.

Carey, J.M. and M.J. Keough. - 2002. Compositing and subsampling to reduce costs and improve power in benthic infaunal monitoring programs. Estuaries, 25(5): 1053-1061.

Clarke, K.R. and M. Ainsworth. - 1993. A method of linking multivariate community structure to environmental variables. Mar. Ecol. Prog. Ser., 92: 205-219.

Clarke, K.R. and R.M. Warwick. - 1994. Change in marine communities: an approach to statistical analysis and interpretation. Natural Environment Research Council, Plymouth Marine Laboratory.

Corbera, J. and M.J. Cardell. - 1995. Cumaceans as indicators of eutrophication on soft bottoms. Sci. Mar. 59(Suppl. 1): 63-69.

Costello, M.J., G. Pohle and A. Martin. - 2004. Evaluating biodiversity in marine environmental assessments. Research and Development Monograph Series 2001, Canadian Environmental Assessment Agency, Ottawa. http://www.ceaaacee.gc.ca/015/0002/0019/index_e.htm

Delamotte, M. and E. Vardala-Theodorou. - 2001. Shells from the Greek Seas. The Goulandris Natural History Museum, Athens.

Dewarumez, J., D. Davoult and S. Frontier. 1992. - Is the "Muddy Heterogenous Sediment Assemblage" an ecotone between the pebbles community and the Abra alba community in the Southern Bight of the North Sea? Neth. J. Sea Res., 30: 229-238.

Dounas, C. and K. Papadopoulou. - 1993. Oceanographic and environmental study of Iraklion Bay. Tech. Rep., Institute of Marine Biology of Crete, Greece (in Greek).

Gómez-Gesteira, J.L. and J.C. Dauvin. - 2000. Amphipods are good bioindicators of the impact of oil spills on soft-bottom macrobenthic communities. Mar. Pollut. Bull., 40(11): 1017-1027.

Graf, G. - 1992. Benthic-pelagic coupling: a benthic view. Oceanogr. Mar. Biol., 30: 149-190.

Gray, J.S. - 2000. The measurement of marine species diversity, with an application to the benthic fauna of the Norwegian continental shelf. J. Exp. Mar. Biol. Ecol., 250: 23-49.

Gray, J.S. and T.H. Pearson. - 1982. Objective selection of sensitive species indicative of pollution-induced disturbance change in benthic communities. I: Comparative Methodology. Mar Ecol. Prog. Ser. 9: 111-119.

Hyland, J., L. Balthis, I. Karakassi, P. Magni, A. Petrov, J. Shine, O. Vestergaard and R. Warwick. - 2005. Organic carbon content of sediments as an indicator of stress in the marine benthos. Mar. Ecol. Prog. Ser., 295: 91-103.

Karakassis, I. and A. Eleftheriou. - 1997. The continental shelf of Crete: structure of macrobenthic communities. Mar. Ecol. Prog. Ser., 160: 185-196.

Koulouri, P., D. Koutsoubas and C. Dounas. - 2000. Structure and dynamics of the infralittoral molluscan assemblages (soft substrate) in Heraklion Bay (Crete, Eastern Mediterranean). Proc. $6^{\text {th }}$ Hellenic Symp. Oceanogr. Fish. (Chios), pp. 355-360. Greece.

Koutsoubas, D. - 1992. Contribution to the study of the gastropod molluscs of the continental shelf of the North Aegean Sea. $\mathrm{Ph}$ D. thesis, Aristotle Univ. Thessaloniki, Greece.

Koutsoubas, D., A. Koukouras, I. Karakassis and C. Dounas. 1992. Contribution to the knowledge of Gastropoda and Bivalvia (Mollusca) of Crete Island (S. Aegean Sea). B. Malacol., 28(1-4): 69-82.

Newell, R.C., L.J. Seiderer and J.E. Robinson. - 2001. Animal: sed- iment relationships in coastal deposits of the eastern English Channel. J. Mar. Biol. Assoc. U.K., 81: 1-9.

Noss, R.F. - 1983. A regional landscape approach to maintain diversity. BioScience, 33: 700-706.

Olsgard, F., P.J. Somerfield, and M.R. Carr. - 1997. Relationships between taxonomic resolution and data transformations in analyses of a macrobenthic community along an established pollution gradient. Mar. Ecol. Prog. Ser., 149: 173-181.

Pearson, T.H. and R. Rosenberg. - 1978. Macrobenthic succession in relation to organic enrichment and pollution of the marine environment. Oceanogr. Mar. Biol., 16: 229-311.

Pérès, J.M. - 1967. The Mediterranean benthos. Oceanogr. Mar. Biol., 5: 449-533.

Pérès, J.M. - 1982. Major benthic assemblages. In: O. Kinne (ed.), Marine Ecology, pp. 373-522. J. Wiley \& Sons, Chichester.

Psarra, S., A. Tselepides, and L. Ignatiades. - 2000. Primary productivity in the oligotrophic Cretan Sea (NE Mediterranean): seasonal and interannual variability. Prog. Oceanogr., 46: 187-204.

Ricciardi, A. and E. Bourget. - 1998. Weight-to-weight conversion factors for marine benthic macroinvertebrates. Mar. Ecol. Prog. Ser., 163: 245-251.

Rueda, J.L., Fernández-Casado, M. Salas, C. and Gofas, S. 2001. Seasonality in a taxocoenosis of molluscs from soft bottoms in the Bay of Cádiz (southern Spain). J. Mar. Biol. Assoc. U.K., 81: 903-912.

Samuelson, G.M. - 2001. Polychaetes as indicators of environmental disturbance on subarctic tidal flats, Iqaluit, Baffin Island, Nunavut Territory. Mar. Pollut. Bull., 42(9):733-41.

Sabelli, B., R. Gianuzzi-Savelli and D. Bedulli. - 1990. Catalogo annotato dei Molluschi Marini del Mediterraneo. Libreria Naturalistica Bolognese, Bologna.

Smith, W. and A.D. McIntyre. - 1954. A spring-loaded bottom sampler. J. Mar. Biol. Assoc. U.K., 33: 257-264.

Thompson, B.W., M.J. Riddle, J.S. Stark. - 2003. Cost-efficient methods for marine pollution monitoring at Casey Station, East Antarctica: the choice of sieve mesh-size and taxonomic resolution. Mar. Pollut. Bull., 46: 232-243.

Todd, J.A. - 2005. Introduction to molluscan life habits databases. Neogene Marine Biota of Tropical America. http://eusmilia.geology.uiowa.edu/database/mollusc/mollusclifestyles.htm

Tselepides, A., K.-N. Papadopoulou, D. Podaras, W. Plaiti and D. Koutsoubas. - 2000. Macrobenthic community structure over the continental margin of Crete (South Aegean Sea, NE Mediterranean). Prog. Oceanogr., 46: 401-428.

UNEP (United Nations Environmental Programme). - 1992. Convention on Biological Diversity-text and annexes. Secretariat for the Convention on Biological Diversity, Chatelaine, Switzerland.

Warwick, R.M. and K.R. Clarke. - 1994. Relearning the ABC: taxonomic changes and abundance/biomass relationships in disturbed benthic communities. Mar. Biol., 118: 739-744.

Warwick, R.M. and K.R. Clarke. - 2001. Practical measures of marine biodiversity based on relatedness of species. Oceanogr. Mar. Biol. Ann. Rev., 39: 207-231.

Warwick, R.M., N.R. Collins, J.M. Gee and C.L George. 1986. Species size distributions of benthic and pelagic Metazoa: evidence for interaction. Mar. Ecol. Prog. Ser., 34: 63-68.

Warwick, R.M., H.M. Platt, K.R. Clarke, J. Agard and J. Gobin. 1990. Analysis of macrobenthic and meiobenthic community structure in relation to pollution and disturbance in Hamilton Harbour, Bermuda. J. Exp. Mar. Biol. Ecol., 138: 119-142.

Zenetos, A. - 1996. Classification and interpretation of the established Mediterranean biocoenoses based solely on Bivalve Molluscs. J. Mar. Biol. Assoc. U.K., 76: 403-416.

Received September 1, 2005. Accepted June 22, 2006.

Scient. ed.: M. Ramón.

Published online October 23, 2006. 
